\title{
RELIABILITY OF EVOKED RESPONSE AUDIOMETRY IN HEARING IMPAIRED YOUNG CHILDREN DURING SLEEP
}

\author{
MICHIHO YODA, M.D.
}

Department of Otolaryngology, Faculty of Medicine, Shinshu University, Matsumoto

(Director: T. Suzuki, M.D.)

In order to evaluate the reliability of the slow vertex evoked response audiometry in young deaf children during sleep, response detectability, rate of false positive decision, agreement between scorers and test-retest agreement were investigated in 6 young children aged 2 to 4 years with hearing impairment of 60 to $70 \mathrm{~dB}$.

The slow vertex evoked response was recorded with a $1000 \mathrm{~Hz}$ pure tone at the intensity levels of $40,60,80$ and $100 \mathrm{~dB}$ above averaged threshold of normal adults. Consecutive 50 stimuli were averaged and 10 averaged traces were obtained at each intensity level and without stimulation per subject. Then 3 trained scorers made independently decisions of presence or absence of an evoked response on a total of 300 traces prepared. For investigating test-retest agreement, a retest was performed 18 months later on 150 traces obtained from 3 out of 6 subjects.

Results obtained were as follows:

1. A marked increase in the response detectability was in changing the level of stimulus intensity from 60 to $80 \mathrm{~dB}$ (from $20.6 \%$ to $63.9 \%$ ).

2. The rate of false positive response was $7.2 \%$ of the traces without simulation.

3. Agreement between 3 scorers was obtained in $77.0 \%$ of the total judgments.

4. More than $90 \%$ agreement was achieved between the first and second judgments with an interval of 18 months.

From the above mentioned results, the conclusion can be drawn that the slow vertex evoked response audiometry during sleep is reliable and valid in young children with impaired hearing.

79A-0844. 11022

\section{難聴幼児睡眠時の誘発反応聴力測定の信頼性についで}

\author{
信州大学医学部耳鼻咽呢科教室（主任：鈴木篤郎教授） \\ 依田美千穂
}

\begin{abstract}
粕言
潜時 $50 \mathrm{msec}$ 以上の slow vertex response を指標と する，いわゆる誘発反応聴力測定（以下 ERA と略称す る）は特に幼小贸の他営的聴力測定飞物いて重要な役割 りを果している。しかし䁳眠時幼児の ERA K各ける反 応の出現は種々の因子飞より左右され，山本 ${ }^{11}$ によれば 正常幼児の睡眠時 ERA K招いては正常成人覚醒時の場

*聼器機能检查法研觉 第 103 報
\end{abstract}

合に比べ反応出現の恒常性が弱く，また俱陽性判定の可 能性む多いゆえに本反岕による乳幼児聴力域值の決定に は改善すべき多くの問題点のあることが指摘された.

しかし山本 ${ }^{11}$ の報告は正常児飞よるものであり，難㮥 児に挌けるこの種の検討は従来はとんどなされていない ので，今回臨床上問題となる $60-70 \mathrm{~dB}$ の中等度難聴児 を対象に，四眠時の反応出現晾々音刺激强度との関係，

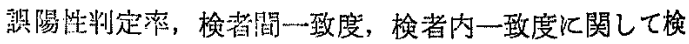


討してみた.

\section{実 験 方 法}

1. 被検者:

実験住 COR または，play audiometry で 60-70 dB の㯖力損失を持つ 2 歳 3 ケ月から 4 歳 3 ケ月までの幼児 6 名妾対象飞眰眠時飞行った(表 1). 病歷及び局所所見 がら，全例感音性難聴であることが推定されている。

2. 加算波形の作成

実験装置の block-diagram を図 1 と示した. 探査, 基蕉，接地電極をそれそれれ被検児の頭頂部，乳突部，前 額部に拓き，増幅器を介し，下記の音刺激に上る誘発反 応を含む原波形をデータレコーダ（TEAC R-200）飞記
表 1 被検者

\begin{tabular}{|c|c|c|c|}
\hline 検者 & 年 齢 & 鎮 静 剤 & 域值（湘定方法） \\
\hline$A_{1}$ & 2葴3ケ月 & $\begin{array}{l}\text { トリクロリールジ } \\
\text { フ プ } 70 \mathrm{mg} / \mathrm{kg} \text { 佳口 }\end{array}$ & $75 \mathrm{~dB}(\mathrm{COR})$ \\
\hline $\mathrm{A}_{2}$ & 4 光 & $\begin{array}{l}\text { 抱水クロラ } \\
5 \mathrm{ml}\end{array}$ & $65 \mathrm{~dB}(\mathrm{COR})$ \\
\hline$A_{3}$ & 3歳3ヶ月 & 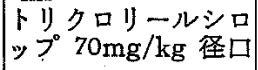 & $\begin{array}{l}\text { 60dB (COR) } \\
\text { 右 } 60 \mathrm{~dB}+65 \mathrm{~dB}\end{array}$ \\
\hline $\mathbf{A}_{4}$ & 4歳3ケ月 & 自然睡 眠 & (play audiome- \\
\hline $\mathrm{A}_{5}$ & 2葴8ケ月 & 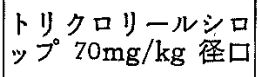 & $\begin{array}{l}\text { try) } \\
60 \mathrm{~dB}(\mathrm{COR})\end{array}$ \\
\hline$A_{6}$ & 2歳8ケ月 & 上 & $60 \mathrm{~dB}(\mathrm{COR})$ \\
\hline
\end{tabular}

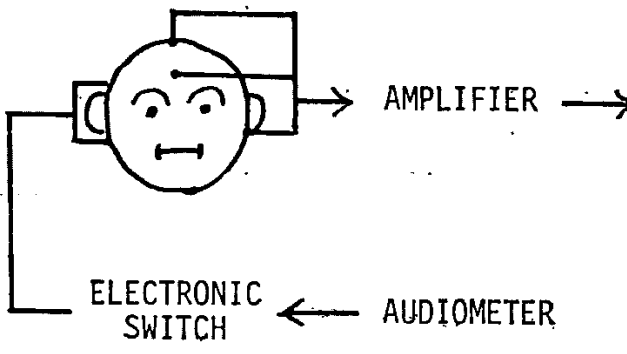

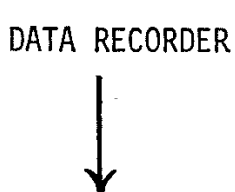

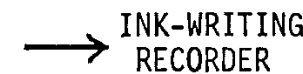

COMPUTER

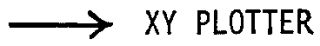

図 1 装置の block diagram

録した. 次に記録された波形をコンピュータ（日本光電 ATAC-201） Kより50 回加算し，XYレコーダ（横河 TYPE 3077）で加算波形火した. 解析時間は 1 “秒とし た. 一方原波形を電力増幅器を介してペン書きレコーダ に送り、モニター用に供した。

被検児を自然飞，あるいは鎮静剤によって睡眠させ （表 1），原波形火より睡眠相)をモニターしながら，中 等度加ら樑睡眠時海って記録を実施した。実験時間は 1 日約 2 時間, 1 被検者につき 2 日間をかけた.

刺激音は $1,000 \mathrm{~Hz}$ 持続 $100 \mathrm{msec}$, 立ち上り立ち下 り $10 \mathrm{msec}$ の純音で, 2 秒飞 1 回のわりでレシーバによ り被検者の两耳に与えた. 刺激音の種類は, 音刺激 $(-)$, $40,60,80,100 \mathrm{~dB}$ (正常成人の平均可聴域值を $0 \mathrm{~dB}$ としてある)の 5 種類で，これらが無作為的な順序で与 えられ，この上ろな条件による50回加算波形を 1 条件あ たり10個作成した. 従って1名の被検者㶤 50個, 総 計で 300 個のサンプルを得え.

このよろにして得られた 1 被検者あたり50個の加算波 形を無作為的順序で並へ，被梌者ごと判定供した。

3. 波形の判定

判定を ERA の波形判定にある程度習䓡している者 3
名に依頼した，判定は各自独立して行ってあらい，各判 定者注実験条件（被検者の年令，自然睡眠加誘発睡眠 か，鎮静郕の薬名と使用量，四眠深度)加知らされ，反応 は陽性また哙性と判定するものとした (forced choice method).

再判定は被検者 3 名についてのみ 1 年半後に行われ， この場合も前回と全く同じ条件で行われた，

\section{実 験 成 績}

\section{I. 陽性判定率}

COR ‡たは play audiometry 值 60-70 dB と推定される中等度難聴児 6 名の 5 種の刺 激条件による ERA 陽性判定率は表 2 飞示したと和りで ある.刺激音の強さとそれに伴う症例ごとの平均陽性判 定率の関係を図 2 亿示した. 山本による正常児の成績る 同四に記入して比較した．この図を見ると，正常児の平 均曲線に比へ，一般飞難聴児では，ある刺激音の所で陽 性判定率が急激化延び，その所で曲線が急峻な勾配を画 いているように見える。そこで，ある音刺激段階で，陽 性判定率が急激炕增加する傾向を正常児の場合と比較す るために，音刺激 $20 \mathrm{~dB}$ の增加飞伴う陽性判定率の增加 の最大值を正常児及び難聴児について表示したのが表 3 
表 2 睡眼時難鳃幼児の陽性判定率 (\%)

\begin{tabular}{|c|c|c|c|c|c|c|c|c|c|c|c|c|c|c|c|c|}
\hline 被検者 & \multicolumn{4}{|c|}{$\mathrm{A}_{1}$} & \multicolumn{4}{|c|}{$\mathrm{A}_{2}$} & \multicolumn{4}{|c|}{$\mathrm{A}_{3}$} & \multicolumn{4}{|c|}{$A_{4}$} \\
\hline 検 者 & $B_{1}$ & $\mathbf{B}_{2}$ & $\mathbf{B}_{3}$ & 平均 & $\mathrm{B}_{1}$ & $\mathrm{~B}_{2}$ & $\mathrm{~B}_{3}$ & 平均 & $\mathrm{B}_{1}$ & $\mathrm{~B}_{2}$ & $\mathrm{~B}_{3}$ & 平均 & $\mathrm{B}_{1}$ & $\mathbf{B}_{2}$ & $\mathrm{~B}_{8}$ & 平均 \\
\hline$(-)$ & 20 & 10 & 30 & 20.0 & 30 & 0 & 0 & 10 & 0 & 0 & 0 & 0 & 0 & 10 & 0 & 3.3 \\
\hline 刺 $40 \mathrm{~dB}$ & 50 & 30 & 40 & 40.0 & 30 & 0 & 30 & 20.0 & 10 & 0 & 0 & 3.3 & 10 & 0 & 10 & 6.7 \\
\hline 激 60 & 30 & 60 & 10 & 33.3 & 10 & 10 & 30 & 16.7 & 10 & 20 & 20 & 16.7 & 0 & 20 & 0 & 6.7 \\
\hline 音 80 & 40 & 80 & 20 & 46.7 & 70 & 90 & 50 & 80.0 & 20 & 80 & 10 & 36.7 & 100 & 100 & 100 & 100.0 \\
\hline 100 & 90 & 100 & 70 & 86.7 & 100 & 100 & 90 & 96.7 & 100 & 100 & 100 & 100.0 & 100 & 100 & 100 & 100,0 \\
\hline 被検者 & & & $A_{5}$ & & & & $A_{6}$ & & 平 & 均 & 值 & 平 & & & & \\
\hline 檢 者 & $\mathrm{B}_{1}$ & $\mathrm{~B}_{2}$ & $\mathrm{~B}_{3}$ & 平均 & $\mathbf{B}_{1}$ & $\mathrm{~B}_{2}$ & $\mathrm{~B}_{3}$ & 平均 & $B_{1}$ & $\mathrm{~B}_{2}$ & $\mathrm{~B}_{\mathrm{s}}$ & 均 & & & & \\
\hline$(-)$ & 20 & 0 & 10 & 10.0 & 0 & 0 & 0 & 0 & 11.7 & 3.3 & 6.7 & 7.2 & & & & \\
\hline 刺 $40 \mathrm{~dB}$ & 40 & 30 & 20 & 30.0 & 30 & 30 & 20 & 26.7 & 28.3 & 15.0 & 20.0 & 21.1 & & & & \\
\hline 激 60 & 20 & 40 & 20 & 26.7 & 30 & 30 & 10 & 23.3 & 16.7 & 30.0 & 15.0 & 20.6 & & & & \\
\hline 意 80 & 50 & 60 & 60 & 56.7 & 60 & 80 & 50 & 63.3 & 56.7 & 81.7 & 48.3 & 63.9 & & & & \\
\hline 100 & 80 & 100 & 70 & 83.3 & 100 & 100 & 100 & 100.0 & 95.0 & 100.0 & 88.3 & 94.5 & & & & \\
\hline
\end{tabular}

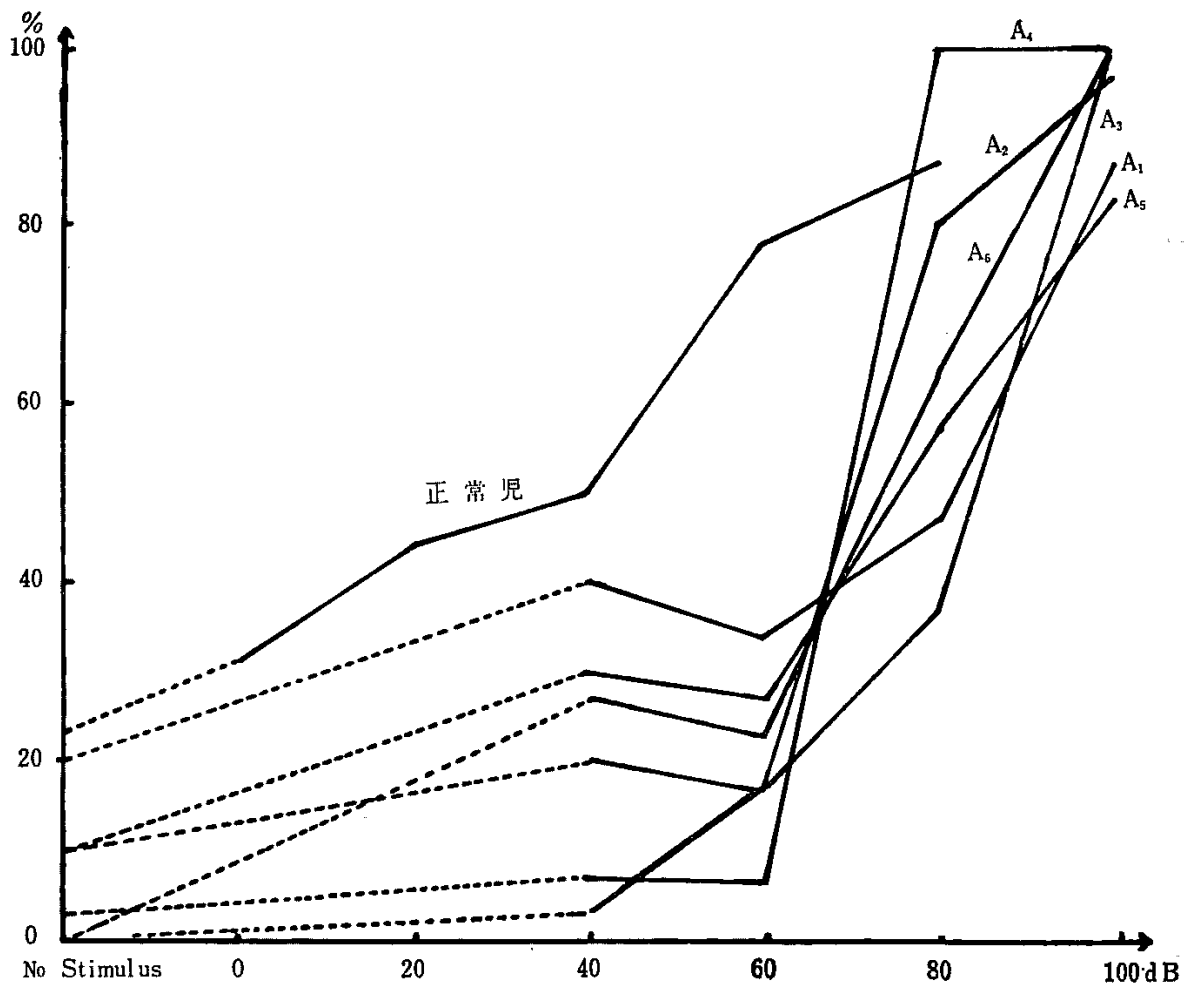

図 2 睡眠時幼児の陽性判定率 
表 3 音刺激 $20 \mathrm{~dB}$ 增强化伴弓陽性判定率差の最大值 (\%)

\begin{tabular}{|c|c|c|c|c|c|}
\hline 正 & 常 & \multicolumn{4}{|c|}{ 児 (山本による) } \\
\hline 検者 & $B_{1}$ & $\mathrm{~B}_{\mathbf{2}}$ & $\mathrm{B}_{3}$ & $\mathbf{B}_{4}$ & 平 均 \\
\hline $\mathbf{A}_{3}$ & 60 & 30 & 60 & 60 & 52.5 \\
\hline $\mathrm{B}_{4}$ & 50 & 40 & 20 & 20 & 32.5 \\
\hline$A_{5}$ & 30 & 30 & 40 & 50 & 37.5 \\
\hline 平均 & 46.7 & 33.3 & 40.0 & 43.3 & 40.8 \\
\hline
\end{tabular}

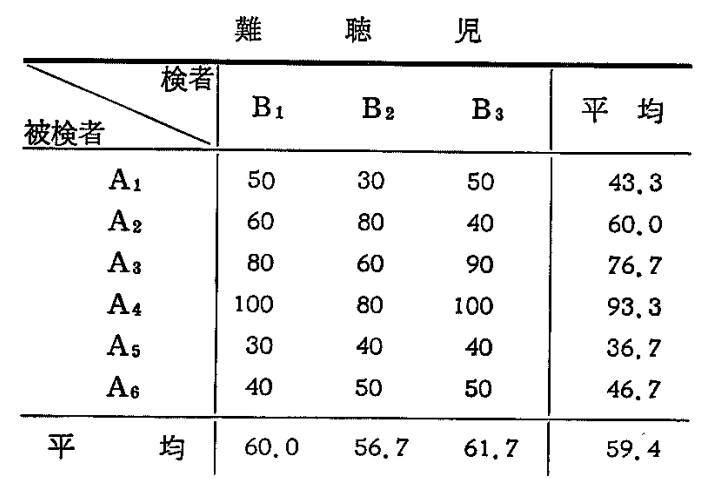

である. 正常児の成績は山本 ${ }^{11}$ の論文を参照して作成し た. 両群の平均の差の検定を行ってみたところ, 危険率 $5 \%$ で有意差があり, 難聴児の方が正常児より音刺激の 強さの堌加飞伴う陽性判定率増加度が高い，すなわち図2 における曲線の勾配が正常児より急峻であることがわか $\supset$,

\section{2. 俱陽性判定率}

音刺激(一)の段階に括ける諨陽性判定率は表 2 K示し たよろ K，判定者または症例により 0 30\%で，総平均 は $7.2 \%$ でる.この值仙山本 ${ }^{(1)}$ 江和ける正常览の場合 の $26.67 \%$ K比べて著しく低い值である.

3, 判定者間一致度

判定者 3 名の判定か $(+,+,+)$ または (,,- , ) となった場合を一致したすのと見なして集計をとると， 表 4 の示すと括りで，全体として $77.0 \%$ の一致度を示 した. 症例間では $\mathrm{A}_{1} 58 \%, \mathrm{~A}_{4}, \mathrm{~A}_{5} 90 \%$ ，最大約 30\% ほどの差が見られる．音刺激条件に括いては，音刺激 (一)では 90\% 近い值を示すが, 被検児の可聴域值の前 後である $60 \mathrm{~dB}, 80 \mathrm{~dB}$ ではそれぞれ 68.3\%，61,7\% の低い一致率を示している.これは判定者間の判定基準

表 4 判定者間一致度 (\%)

\begin{tabular}{c|rrrrrr|l}
\hline $\begin{array}{c}\text { 被検者 } \\
\text { 竟刺 }\end{array}$ & $\mathrm{A}_{1}$ & $\mathrm{~A}_{2}$ & $\mathrm{~A}_{3}$ & $\mathrm{~A}_{4}$ & $\mathrm{~A}_{5}$ & $\mathrm{~A}_{6}$ & 平均 \\
\hline$(-)$ & 80 & 70 & 100 & 90 & 80 & 100 & 86.7 \\
$40 \mathrm{~dB}$ & 60 & 70 & 90 & 80 & 80 & 100 & 80.0 \\
60 & 40 & 70 & 80 & 80 & 60 & 80 & 68.3 \\
80 & 40 & 50 & 30 & 100 & 80 & 70 & 61.7 \\
100 & 70 & 90 & 100 & 100 & 70 & 100 & 88.3 \\
\hline 平 均 & 58 & 70 & 80 & 90 & 74 & 90 & $77.0 \%$ \\
\hline
\end{tabular}

の個人的差異が transition zone に和いて最も著明に露 呈されるためであろろ.

\section{4. 判定者内一致度}

被検者 3 名の計 150 個のサンプルを 3 人の判定者が 1 年半後に再判定して, その間の一致度をみた. 結果は表 5 亿示した。 両検查間の間隔が長いにすかかわらず, “3 人の検者とすに 90\% 以上のかなり高い一致度を得るこ とができた。これは検者個人の判定基準がかなり維持さ れることを示している. しかし $60 \mathrm{~dB}, 80 \mathrm{~dB}$ 飞扣いて は80\%台とやや低く，やはりこの段階に打ける判定の困 難さを示している.

表 5 判定者内一致度 (\%)

\begin{tabular}{c|rrr|l}
\hline $\begin{array}{c}\text { 音刺 } \\
\text { 激強度 }\end{array}$ & $\mathrm{B}_{1}$ & \multicolumn{1}{c|}{$\mathrm{B}_{2}$} & $\mathrm{~B}_{3}$ & 平 釦者 \\
\hline$(-)$ & 93.3 & 100.0 & 96.8 & 96.7 \\
$40 \mathrm{~dB}$ & 100.0 & 93.3 & 83.3 & 92.2 \\
60 & 86.7 & 83.3 & 83.3 & 84.4 \\
80 & 93.3 & 76.7 & 90.0 & 86.7 \\
100 & 100.0 & 100.0 & 96.8 & 98.9 \\
\hline 平 均 & 97.3 & 90.7 & 90.0 & $92.7 \%$ \\
\hline
\end{tabular}

\section{考按}

正常幼肾睡眠時の ERA 陽性判定率江関しては，すで K Appleby')，田 ${ }^{10)}$, Suzuki \& Taguchi ${ }^{8)}$ Rapin $5^{6)}$,

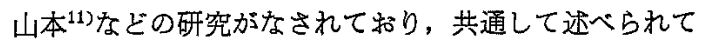
いることは, 成人党醒時と比較して, 同一音刺激強度に於 ける陽性判定率が悪いということである.さらに山本 ${ }^{11)}$ は音刺激強度と出現率の関係を示す図に括いて（図2 参 照), 幼児殹眠時の曲線の勾配が 成人喾醒時に比べて著 しく楥かで，ある音刺激段階の間で急激に出現率が増す

$8-13$ 
というような傾向の認められないことを指摘している. これに比べ回著者の稣討した域值 60-70 dB と推定さ れる難聴児に挌いては，因2亿示すようK，多くはある 音刺激段階から曲線の勾配が急峻飞立上って扣り,この ことはある段階に招ける音刺激の強さの一定の增加に伴 弓陽性判定率増加度吕難聴児は正常児飞比べ有意の差を もって高いという表了の成績によっても証明されてい る.この事実は恐らく，感音性難聴耳の持つ recruitment 現象即ち域值上刺激音の loudness の急激な堌強による 誘発反応の振幅の増加と関係あるものであるろ. 既に Cody $5^{2)}$ は成人の各種難聴耳と正常耳との本反応を比 較し，(1) 域值飞括ける平均反応振幅が正常耳群炕比へ て, 感音性難恥耳の方が大であること，(2) 入出力曲線 の勾配が感音性難聴耳群の方が大であることを報告し，

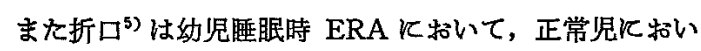
ては ERA の平均域值の方が, COR 域值より $10.5 \mathrm{~dB}$ 高いが，高度難聴児に招いては反対飞 COR の方が 2.5 $\mathrm{dB}$ 高いことを持摘し，その原因は recruitment Kある と推定している. 今回の著者の成績もこれらの報告中の 成績と同一要因炕るるのと思われる。いずれにせよ，

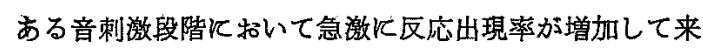
るということは，反応域值の決定上極めて有利な条件で あって, 感音性難聴幼児の場合の方が正常児上りも信頼 性の高い判定ができることを意味している.

俱陽性判定率減してはいずれも正常者を対象にいく つかの研究がなされており，1971年 Rose ら》は覚醒時 成人 50 名に判定者 6 人で12 24\%，1972年飞 Rapin $5^{6)}$ は覚醒時幼小児 44 名に判定者 2 人で $14,21 \%$, 同じく睡

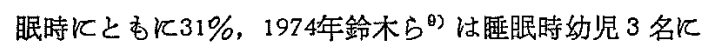
判定者 5 人で10 35\%，1974年山本 ${ }^{11}$ は睡眠時幼児 3 名 飞判定者 4 人で $0 ~ 36.7 \%$ (平均 $26.6 \%$ ) の成績を得て いる. 今回の実験で性眠時難聴幼児 6 名飞判定者 3 人 で0〜30\% (平均 7.2\%)．の低い值を得ることができた. この原因について確定的なことは言えぬが，鈴木らの゙が 既に述べているように, 望陽性判定の頻度は睡眠深度に 強く影響されるので，今回の被検児中には此較的浅睡眠 時飞記録され，自発脳波波形と反応波形亡の混同が起こ り難しかった例が多加九ためと考光られる。しかし一 方 $40 \mathrm{~dB}$ 音刺激段階缕, 今回の被検児炕とっては恐らく 域値下の刺激であり，この段階での陽性判定は諆陽性判 定々見てよい乞思われるが，この段階での陽性判定率は 平均 $21.2 \%$, 前記 $7.2 \%$ 上りかな大きい.この相遀 の原因は不明である。
判定者間一致度については, 1971年 Cohen $5^{33}$ は 20 例の睡眠時幼児の 464 個のサンプルを 3 人の判定者が判 定し，全く一致したものが49\%であるとしている. 1974 年山本 ${ }^{11)} 3$ 名の棰眠時奻览の 180 個のサンプルを4人 の判定者か判定し $55.6 \%$ の一致度を得ている. 今回著 者は 6 名の睡眠時難聴幼児の 300 個のサンプルを 3 人の 判定者に供し総平均 $77.0 \%$ と前 2 者の成績よりやや高 い一敨度を得た. しかし $60 \mathrm{~dB}$ 及び $80 \mathrm{~dB}$ 段階てはそ れそれ 68.3\%，61.7\%であり，いわゆる transition zone K执いては判定者間の判定基準の相迺のあること がかなり明瞭に示されている.

判定者内一致度については, Cohen $5^{33}$ は $59.75 \%$, Rose $5^{7)}$ は $65 \sim 88 \%$ ，山本 ${ }^{11}$ は $77.8 \% ， 92.2 \%$ の成 績を得ている. 難聴幼児を対象とした今回の成綪法前 3 者比へ，90.0，90.7，97.3\%と高い一致度を得た。 こ のことは判定者の判定基準の恒常性が高いことを示すす のである。

以上睡眠時難聴幼児に括ける ERA K㔚ける反応の陽 性判定率を種々の角度加ら検討してきた.これらを給合 してみて, 正常児化べ域值上音刺激による反応出現の 恒常性が高く従って判定の信頼性す高いということが言 える. 证常児を对象とした ERA 亿関する最近の研究の 傾向として, 反応出現の恒常性の低さと誤陽性判定率の 高さ，判定の信頼性の低さのゆえ飞， ERAの他営的聴 力測定飞乱ける有効性が少からず問題視されている、し かし，今回の成縝からい充は，少くとす難聴児を対象と する限り，ERA の有効性は再認識さるべきものではな いかと考える.

\section{結語}

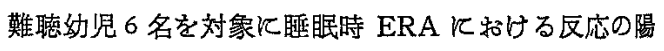
性判定率飞ついて検討し, 正常児化比へ高い恒常性と低 い證陽性判定率を得た.このことにより難聴児を対象と する場合の他覚的聴力測定に和ける ERA の有勃性を再 認識した。

\section{文献}

1) Appleby, S.V.: The slow vertex maximal sound evoked response in infant. Acta oto-laryng. suppl., 206; 146-152, 1965.

2) Cody, D.T.R., Griffing, T. \& Taylor, W.F.: Assessment of newer tests of auditory function. Ann. Otol. Rhin. Laryng., 77; 686-705, 1968.

3) Cohen, M.M., Rapin, I., Lyttle, M. \& Schm- 
mel, H.: Auditory evoked response (AER): Consistency of detection in young children. Arch. Otolaryng., 94; 214-219, 1971.

4) Dement, W. \& Kleitman, $N$,: Cyclic variations in EEG during sleep and their relation to eye movements, body motility and dreaming. Electroenceph. clin. Neurophysiol., 9; 673-690; 1957.

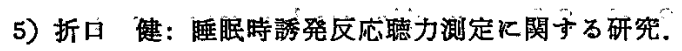
日耳鼻，7.1, 1440-1453，1968.

6) Rapin, I., Schimmel, H. \& Cohen, M.M.: Reliability in detecting the auditory evoked response (AER) for audiometry in sleeping subjects. Electroenceph. clin. Neurophysiol., 32; 521-528, 1972.

7) Rose, D.E., Keating, L.W., Hdgecock, L.D., Schreurs, K.K. E Miller, K.E.: Aspects of acoustically evoked responses: Inter judge and intrajudge reliability. Arch. Otolaryng.; 94; 347-\$50, 1971.
8) Suzuki, T. \& Taguchi K.: Cerebral evoked response to auditory stimuli in young children during sleep. Ann. Otol. Rhinol. Laryngol., 77; 102$110,1968$.

9）鈴术篤郎，田口喜一郎，山本香列：咶眠時幼児の㮇

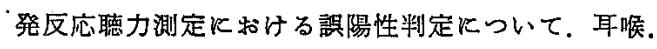
$\therefore 46,455 \sim 459,1974$.

10)田口喜一郎: ‘乳幼児誘発電位㯖力測定. Audiology Japan, 9; 231-24l, 1966.

11）山本香列：誘発反応㯖力測定记括ける判定に関する 研究. 日耳留，77；641-649，1974。

稿を終ると䠦み，御懇篤なる御指導と御校閲を晹つた 恩師鉿木篤郎教授飞深甚路る謝意をささげます，また研 究に際して御協力いただいた田口砶一郎临師, 山本香列 先生飞深く感謝いたします。

（原稿受付 昭和 51.2.2日) 